biology and molecular biology in particular should be separated from this mechanism, but MRC (dwarfed as it is by the recent spectacular growth of private charitable research funds) would still have an important function in fields such as human genetics. But direct academic support (now small) by NERC and AFRC should be transferred to the new SERC, and should themselves be merged into an applied research council (together with SERC's own interests in industrial projects, as in biotechnology and electronics). And an attempt should be made, perhaps by means of an applied research council, to breathe new life into the best of the Rothschild recommendations in 1971 - that departments of the British government should be made competent in knowing what research could do for them.

The benefits of some such reorganization would be several, not the least that it would be easier for the several research councils to tell what they are for. Only in that way is British academic research likely to win the benefits of stability of which it has been too much deprived in recent years. The need for acting quickly is all the more necessary now that the British university system has been set off on the long and painful road towards the concentration of research resources on chosen institutions and departments. Especially with that prospect, it is unseemly that grown men should be quarrelling in the House of Lords about questions such as whether photosynthesis belongs more properly with AFRC or SERC; they should instead be wondering about the restoration of the British research enterprise to good health. But a radical change along these lines would have the further advantage that the armies of selfless men and women who at present, by their membership of research councils and their committees, are all perpetually brooding about the same vast range of intractable problems would have a more comprehensible set of issues on their plates.

\section{Second term, second try}

Will the same recipe for research serve $M$. Mitterrand as well during his second presidency?

THE return of President François Mitterrand in last Sunday's election will not restore the mood of French science to that just eight years ago, when Mitterrand's first research minister, JeanPierre Chevènement, set about throwing money at almost every problem in sight. Not only is $\mathrm{M}$. Hubert Curien, Chevènement's successor (with a much less grand portfolio of interests) a naturally more cautious man, but Mitterrand himself is also wiser as well as older. Chevènement was asked to carry the torch for research at a time when the president himself believed that France was ready for a thoroughgoing reform of its social and economic institutions. In the event, the reform came to a halt when France's bankers took fright at the government's deficit, and when the voters who re-elected President Mitterrand on Sunday gave him an assembly dominated by his opponents. Mitterrand would not relish a re-run of that course.

Nor need he take the risk. The most curious feature of the past eight years in France is that, over-optimism and false starts notwithstanding, so much has been done to change the climate for science and technology. While the roots of this process go back to the gaullist era at the end of the 1950s, Mitterrand's first spell in office as the first socialist president of this republic has brought a rich harvest of technical progress and, more important, a dramatic deepening of the French research enterprise at university and research institute laboratories. French research and French industry are in good shape, and it has ceased to be a marvel that the telephone system works. The worm in the apple is merely that France remains prone to the seductions of flashy schemes, among which its devotion to man-in-space is only the most conspicuous. Task-directed programmes may have served well in the first of Mitterrand's presidencies, but Curien would be well-advised, on his behalf, to watch out for their dangers on this second round.

\section{More embryo research?}

The British committee overseeing the practice of IVF may not have much life ahead of it.

This time next year, the British government will almost certainly have carried legislation onto its statute book to regulate research with fertilized human eggs. The government has been explicit about its policy (published last November, see Nature 330, 407; 1987)) - clinics and practitioners that practise in vitro fertilization will have to be licensed, commercial surrogacy will become illegal and so on, but the question of whether research with fertilized human eggs will be allowed will be determined by the British parliament. On that part of the government's intended bill, to be published in the autumn, Members of Parliament will not be dragooned or cajoled into one or other of the voting lobbies, but will instead be allowed to decide for themselves.

This is the sense in which last week's third report of the Voluntary Licensing Authority (VLA) for in vitro fertilization (IVF) and embryology may be the last-but-one of its kind. The committee owes its existence to the correct estimation of the Medical Research Council and the Royal College of Obstetricians and Gynaecologists that, in the absence of legislation, selfregulation would be prudent. But the committee has no statutory backing, but must rely on practitioners and researchers to collaborate by requesting licences to do what they seek. Those concerned are sufficiently aware of the benefits research will derive from public trust that there is not a scintilla of doubt that voluntary applications have been comprehensive. The fear now is that that state of grace may not continue.

Yet the research recorded in this third report (a total of 18 projects voluntarily notified in 1987) is also a vivid proof of how innocuous are people's ambitions. Almost all the projects from 1987 and earlier years are concerned with the technology of IVF itself - what are the determinants of success in IVF procedures and how might success-rates be improved? There are just two (of 18) projects in which people are using genetic probes to look for genetic defects in fertilized eggs. This is hardly the Frankenstein stuff of which people have been worrying.

The report provides telling evidence both of the demand for IVF in Britain and of the still poor rate of success even with present techniques. That there should have been 4,670 patients at IVF clinics in 1986 is one measure of the demand for the service. That a large number of women should have endured a total of more than 7,000 oestrus cycles after being implanted with fertilized eggs in the hope of becoming pregnant is a measure of the sacrifices people are prepared to make to relieve infertility. That there were only 605 live births from all this effort is a proof that IVF remains a potent source of high hope disappointed. The report also carries telling evidence of how further research is almost certain to improve success. At six of the larger British centres, responsible for treating two-thirds of all infertile patients, nearly a fifth of all egg transfers led to a live birth, more than six times the success rate at the smaller clinics. IVF is plainly a technique in great demand which is much in need of improvement.

That is the context in which the British parliament (and others elsewhere) should regard the issue it will face later in the year. The crying need is for a substantial improvement of the technique. To prohibit investigations leading to improvement would be to perpetuate the present state of affairs in which thousands of women each year take pot-luck with a new technique, and are cruelly disappointed four times out of five. The VLA itself, having produced the evidence, "strongly recommends" that the liberal option of notified research with strict safeguards should be applied to embryo research, but prudently, it rests its case at that. But this declaration is set in such a detailed and constructive appraisal of the government's proposals that it will require great obstinacy by parliamentarians to reject it. Unfortunately, that is no assurance that they will not. 